\title{
INTERVIEW WITH JOHN GLEDSON
}

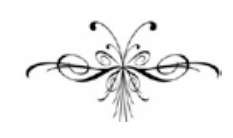

Gustavo AlthofF $^{1}$

$\mathrm{J}$ ohn Gledson (born in Beadnell, Northumberland, England, in 1945) is a retired professor of Brazilian Studies at the University of Liverpool. He is also one the most renowned specialists in the work of Brazilian writer Machado de Assis. He has published three books on Machado in Brazil: Machado de Assis: ficção e história (Paz e Terra, 1986), Machado de Assis: impostura e realismo (Companhia das Letras, 2005) and Por um novo Machado de Assis (Companhia das Letras, 2006). He has edited three volumes of Machado's "crônicas" and two anthologies of his short-stories, the most recent one being "50 contos de Machado de Assis" (Companhia das Letras, 2007). He is the translator of many different books from Brazilian Portuguese into English, among them Machado's novel "Dom Casmurro", a colection of his short-stories entitled "A chapter of hats and other stories" (Bloomsbury, 2009), and a seminal Literary Criticism work on Machado called "A Master on the Periphery of Capitalism: Machado de Assis [Um mestre na periferia do capitalismo: Machado de Assis] (Duke University Press, 2001), by Roberto Schwarz. In this interview an attempt was made to critically assess what Gledson wrote about Machado and translation.

SCIENTIA TRADUCTIONIS: When did you start to get interested in translation? What part has translation played in your professional career? How did your participation in Translation Studies come about? With a doctorate in Comparative Literature, what is your view of the relationship between the two disciplines, and what benefits can it bring?

JOHN GLEDSON: The first complete book I translated was a collection of essays by Roberto Schwarz, published under the title of Misplaced Ideas (i.e. "ideias fora de lugar") in 1991, by Verso (the imprint of the New Left Review). It arose, more or less, from necessity: both the publisher and the author wanted the book to appear, and since I am a friend of Roberto's, and very used to his work, its style and its difficulties, I was the obvious person to do the work. Actually, I think it's one of the most useful tasks I've ever undertaken, because, although the book doesn't sell in huge quantities, its ideas are very powerful, and they needed to enter the

\footnotetext{
${ }^{1}$ Gustavo Althoff has a major in Social Sciences from Universidade Federal de Santa Catarina (UFSC) and a $\mathrm{PhD}$ and postdoctoral degree in Translation Studies from the same institution. He is currently coeditor-in-chief of Scientia Traductionis.
} 
bloodstream of thought about the relationship between Latin America and what was then called the "First World". I have translated two further books of Roberto's since, A Master on the Periphery of Capitalism: Machado de Assis (2001) and Two Girls (2012). There was virtually no career incentive to do the work, which was looked on as inferior to more "creative" or "abstract” projects in terms of one's CV - a situation most people are familiar with.

In 1994 I had to retire at a relatively young age (49) after a heart attack. It was then that translation began to move to centre-stage. Soon after my retirement, I got an offer to translate Dom Casmurro for a new series (Library of Latin America) launched by the Oxford University Press in New York. It was a complete coincidence: but it was very good for me, in all kinds of ways. I can't say that the relationship with the publisher has been brilliant: the cover (which they chose over another I had suggested) is irrelevant to the book; I had no percentage, and have no idea of how many copies have sold (once you've got your fee, you don’t exist).

Then, for a few years, I became something like a professional translator. Through a series of contacts between Companhia das Letras (who had published a book of mine - Machado de Assis: Impostura e realismo) and Bloomsbury (in the persons of Luiz Schwarcz and Liz Calder) I translated books on varied topics (self-deception, the public image of Dom Pedro II, the city of Rio de Janeiro, the screenplay of Central Station [Central do Brasil]), and some modern fiction - notably, I have translated virtually all of the fictional work of Milton Hatoum, of whom I am a great admirer, and who was very kind and helpful during the process. I should say that I was well paid for this work - much better than someone translating in the other direction, from English into Portuguese, would have been.

My involvement with Translation Studies came much later, as a result of an invitation from the PGET (Programa de Pós-graduação em Estudos da Tradução [Postgraduate Translation Studies programme]) of the Federal University of Santa Catarina, in 2005. I developed a slight panic when I realised I would have to teach a topic I had only practical knowledge of, and I remember trying to read George Steiner's After Babel on the plane, and being not much the wiser! I need not have worried - I found that the students enjoyed the practical approach. But I was also exposed by colleagues to Translation Studies as a topic, which was very good for me, though in ways I find hard to define. If I tried to say that I was influenced by any particular theory (those of Antoine Berman, for instance, whom I read with great pleasure), that would be a slight distortion, I think. To put it as exactly as I can without sounding pretentious, I think that I have come to see myself more as a mediator between different kinds of texts and their possible audiences. The stories and crônicas ${ }^{2}$ of Machado de Assis, which I have produced (Brazilian) editions of, are other cases in point - the crônicas in particular need extensive annotating if they are to be understood by a modern audience. This even shades off into what might be thought of as "pure" literary criticism - what I try to do in this aspect of my work is to make the author (Machado, Carlos Drummond de Andrade, or whoever) live in more ways, to help the reader read.

The last part of your question I find hardest to answer: my degree is from 1979, and the "comparative" part of my thesis on Drummond was a traditional study of influence (published since in Influências e impasses: Drummond e alguns contemporâneos (2003), with very little to do with translation. More recently, I have come to realise that there is a huge iceberg having to do with translation underneath comparative studies. Just to stick to Drummond, recently a wonderful edition of his Poesia traduzida [Poetry in translation], edited by Júlio

\footnotetext{
${ }^{2}$ A regular newspaper column primarily intended to be humorous and entertaining.
} 
Castañon Guimarães, has been published by Cosac e Naify, and I keep on wondering if studies of his translations and their history would lead anywhere: why translate François Mauriac (Thérèse Desqueyroux [Uma gota de veneno] in 1942 (Mauriac was conservative and Catholic, but firmly opposed to German occupation and to the Vichy régime) and Les Liaisons dangereuses [As ligações perigosas (1948)] (which Drummond did without a contract); and how about his translation (as part of a team), of one volume of À la recherche du temps perdu, Albertine disparue (A fugitiva, 1956)? I confess I had bought it without having opened it - now I do, I see some very interesting notes, some referring to the Spanish and English translations. Also, I saw a comment the other day (which I can't now relocate) that there was something suitable about him translating this novel, at this time (1956), when many of his poems dealt with love and loss: "Amar o perdido / deixa confundido / este coração" etc.

\section{ST: What made you translate Machado de Assis? Was it on your initiative or were you invited?}

JOHN GLEDSON: As I have said, the first translation of the two I have published, Dom Casmurro (1997), and the collection of stories A Chapter of Hats, which appeared in 2008, came essentially from publishers' initiatives, though the fact that I was in continual contact with Bloomsbury must have facilitated the translation of the collection of stories, which I had long wanted to do - it's no accident, either, that it was done in the centenary year of Machado's death. Two previous collections had been published that I knew of, by Helen Caldwell and William Grossman (The Psychiatrist and Other Stories) and Jack Schmitt and Lorie Ishimatsu (The Devil's Church and Other Stories) $)^{3}$ but I thought a new collection would be worthwhile, partly because of the sort of stories chosen (the first collection, for example, focused on the more "abstract" tales from Papéis avulsos), and for reasons of exactitude and tone. I think I have been vindicated, though I wish the sales in the English-speaking world were greater - perhaps they will be, now it is going into e-book form. A Chapter of Hats had some nice reviews, notably one by Eileen Battersby of the Irish Times, which compares Machado favourably to Paul Auster!

\section{ST: Has translating Machado changed your relationship with his texts? To put it another way, as an interpretative activity which involves more than just reading, but also rewriting, recreation, making a new complete text, however we want to put it, has it allowed you to see aspects of Machado's prose which you hadn't seen as clearly or as immediately before?}

JOHN GLEDSON: The answer to that is yes - what is difficult to do is explain in what ways, because a lot of the changes are subtle ones, under the radar of the conscious mind. What I have found useful and interesting is bringing some of these unconscious changes a little nearer consciousness, in particular in the two "essays" - one complete essay and another part of one - I have written on two complete stories, "Singular ocorrência" [A singular occurrence] and "Dona Paula". ${ }^{4}$ It's easy (and no doubt true) to say that one's appreciation of

\footnotetext{
${ }^{3}$ See the article Marcas de uma travessia: aspectos de seleção, tradução e publicação de contos de Machado de Assis em inglês by Válmi Hatje-Faggion, published in this very issue, for information on other collections.

${ }^{4}$ See GLEDSON, John (2012). “Traduzindo Machado de Assis: 'Dona Paula’”. In: Guerini, Andréia; Freitas, Luana Ferreira de; Costa, Walter Carlos (Orgs.). Machado de Assis: Tradutor e Traduzido. Tubarão: Ed. Copiart; Florianópolis: PGET/UFSC. See also GLEDSON, John (2006). “Traduzindo Machado de Assis”. In: Ensaios premiados: a obra de Machado de Assis. Ministério de Relações Exteriores. pp.96-118. This second essay was republished bilingually in this very issue of Scientia Traductionis.
} 
Machado's concision, his irony, his perception of the details of human character, his use of various narrative distances, increases. This is a continuous process while you are working on a translation, but I like to keep such things in the back of my mind while I'm working, to avoid the risk of "falling in" - I'm referring to an illuminating metaphor from Paul Valéry (I think, from "Poésie et pensée abstraite"), where he says that writing poetry is like dancing on a plank over an abyss - if you look down, you'll fall. On a humbler level, the same is true of translation. For that very reason I find it hard to find examples of specific difficulties or successes in my translations - they have fallen into the pit of forgetfulness, and to resurrect them is either impossible or even painful, like rewriting something you've just written and has been accidentally deleted on the computer.

The cases of the two stories I have dealt with are a bit different: there, I undertook studies of complete translations that had been finished some time before, and so could look at with a certain amount of distance. In the first, "Singular ocorrência", I was led to a curious confirmation of Roberto Schwarz's highlighting of the importance of the (delicate matter of) favour in Machado's work; in the second, to the vital interaction of irony and metaphor in "Dona Paula": I had recourse at the end to a somewhat imprecise notion that these things "aerate" the text, let it "breathe" perhaps. It's nice to know that reconsideration of one's own process can lead to a more perceptive view of both the content and the style of a work.

\section{ST: What has the reception of your translations of Machado been like? Have they been received in different ways in different countries - for instance, in the US and the UK?}

JOHN GLEDSON: To be quite honest, I don't know. Nowadays, reviewing books has become less important to the periodicals and Sunday newspapers, and so there is less material to go on - nor have I seen anything from the US. The alternatives are the reviews that appear on websites like Amazon - but they are often so spotty and idiosyncratic that they don't give the sense of a reading public, national or otherwise. I remember one or two interesting reviews, like the Eileen Battersby one quoted earlier, or a long, excellent one by A.S. Byatt on my translation of Dois Irmãos (The Brothers), ${ }^{5}$ but in general I don't know much about the reception of the books, and of course less about the translations. You can feel the reviewer hunting for a new adjective - zesty, crisp (a big favourite), muscular, etc. etc. - to be nice to the translator whom, of course, they can't, in most cases, judge, at least on the grounds of accuracy. Very few focus on the translation itself, with certain exceptions: like several that have appeared lately of Clive James' new translation of the Divine Comedy.

ST: What is your view of the reception of Machado in other languages and cultures? Do you see differences in the amount of attention given by publishers to translations of his work? Is there a greater value put on his literary status outside the English-speaking world?

JOHN GLEDSON: Looking at the record of translations of Machado in Joana Ivete Duna Magno’s Brazilian Authors Translated Abroad (Fundação Biblioteca Nacional, 1994), English translations have appeared slightly later than Spanish and French (apart from a few exceptions, like the French translations by Adrien Delpech [1910 and 1911] or a Spanish translation of Esaú e Jacó [1905!]), but in the same (if not greater) numbers, and with the

\footnotetext{
${ }^{5}$ BYATT, A. S. Down a river of stories. The Guardian, London, 1 June 2002. Culture. Books. Available at: <http://www.theguardian.com/books/2002/jun/01/asbyatt>.
} 
same kind of publisher. ${ }^{6}$ Things may have changed since, but I doubt if significantly. There have been translations into many other languages, of course - Czech, Catalan, Dutch, Italian, Rumanian, etc.; I was recently at a launch of the first Norwegian translations of Dom Casmurro and Memórias póstumas de Brás Cubas, which have been done into all the Scandinavian languages. In English, where reception has been patchy, ${ }^{7}$ there is a phenomenon we could call succès d'estime: famous writers and cultural figures like Salman Rushdie, Harold Bloom, Woody Allen, Susan Sontag, join in a chorus of praise, and the important critic Michael Wood has written perceptive articles in the New York Review of Books (partly in dialogue with Roberto Schwarz). Gradually, it is to be hoped that the situation will change, but I think it would be wrong to affirm that Machado is less respected in the English-speaking world than outside it (excluding Brazil, of course!).

ST. What is your opinion of the use of paratexts, like translator's introductions, footnotes, prefaces, afterwords etc., as help to interpret the translated text? Do you think that such things should (always) accompany translations of Machado, so as to give them a literary and historical context?

JOHN GLEDSON: A little historical context first: when Machado was first published in English, in the early 1950s, the novels and stories came (almost completely) without footnotes, though with introductions, sometimes of limited value (one informed us that Machado's mother was "Spanish, from the Azores"!). This was normal in those days - Machado was not that distant in time, and literature was, it was thought, self-sufficient. He was published, along with Conrad, Henry James and others in the "Penguin Modern Classics" series - and they too needed no notes. Now, there are numerous rival editions of Conrad and James with good introductions and notes, and I think Machado needs the same treatment - perhaps a little more, because there is always a problem of introducing a work from a different culture and language, written for a different immediate audience, even if it has international aspirations, which Machado certainly had. Machado in fact can appear to be more in need than most, and almost to put foreign readers off - we can begin with the title of Dom Casmurro, and the narrator's prohibition to look up the word casmurro in the (Portuguese!) dictionary. Although he very much wanted to be read abroad, he was certainly not prepared to feign that Brazil was just like anywhere else.

On the other hand, we have to be sure not to let necessary information slip over into interfering interpretation. Notes are necessities, and do improve the reader's understanding, but when the translator-editor pokes his or her nose in and blithely tells us what this or that image "means", what we are to think of such and such a character, and - worst of all - how the story is going to end, it's worse than having no notes at all; we should be self-effacing mediators, not protagonists. Dom Casmurro is a particularly difficult case - above all, I think it is quite wrong to tell the reader that there is a problem with the book (i.e. did the adultery between Capitu and Escobar really happen?). Not so much in Portuguese, of course, because 99\% of people already know there is a problem: but in the introduction to my translation, I deliberately avoided treading on the topic.

\footnotetext{
${ }^{6}$ For more information on the translations into Spanish see: CARDELLINO Soto, Pablo (2012). “Traducciones de Machado de Assis al español”. In: Guerini, Andréia; Freitas, Luana Ferreira de; Costa, Walter Carlos (Orgs.). Machado de Assis: Tradutor e Traduzido. Tubarão: Ed. Copiart; Florianópolis: PGET/UFSC.

${ }^{7}$ See above all Daphne Patai’s essay “Machado in English”: PATAI, Daphne. "Machado in English”. In: Graham, Richard.Machado de Assis: Reflections on a Brazilian Master Writer. Austin: University of Texas Press (1990). pp. 85-116.
} 
All in all, we have to be sensible, minimalist, and respect the context - a story by Machado may need one or two short notes, a crônica nine or ten, some quite extensive (to quote from contemporary newspapers, for instance). It comes back to the notion that whatever one is doing (translating, editing) one is mediating between a writer and his situation, and a reader who of course varies from genre to genre, from language to language, from country to country - and his or hers.

ST: It's common knowledge that Machado's stories are relatively unknown. Chris Power, in the "Books blog" in The Guardian, recently put it this way: "The Brazilian Joaquim Maria Machado de Assis is, to English-language readers, perhaps the most obscure of world literature's great short-story writers." ${ }^{8}$ In contrast to this, the stories of Chekhov and Maupassant, recognised masters of the genre and Machado's contemporaries, are very often translated, and available on the Internet. This situation leads us to the following question: "What is the Englishspeaking public missing by its ignorance of Machado de Assis?”

JOHN GLEDSON: It is difficult to say - as it might be difficult to define the "uniqueness" of Chekhov and Maupassant too: and it is worth saying that though they all started writing important stories at around the same time, Machado was ten years older than Maupassant and twenty older than Chekhov. It's useful, perhaps, to distinguish between the more "abstract", pseudo-philosophical stories of Papéis avulsos and the later, more realistic ones, set in Rio. They are very different, and the first attempt to introduce his stories to the English-speaking world concentrated on the first group. I'm not sure this was a good idea, and tried the other tack in A Chapter of Hats. I think the second group (which are also the large majority, and have proved most popular with Brazilian readers), are, in the end, more individual, and more obviously Brazilian (or carioca, to be exact). I'm not sure if Eileen Battersby is quite right when she refers to the "elusive offbeat surrealist effect" of these stories in her Irish Times review, but she has caught something of Machado's individuality. It certainly is elusive, and that is part of the trouble. Time and again, I am delighted by little details of the stories, their ironies, their understated sarcasms - and I wonder if I have found the right English equivalent, to produce the same kind of (often inward, semi-conscious) smile or laugh.

ST: In the same Guardian blog, Power refers to something you said about the difficulty of translating Machado's stories: “Machado's most recent English translator, John Gledson, says the difficulty of translating him is capturing the right balance of distance, understanding and sympathy." Could you elaborate on this a little more and give examples of how you dealt with this tripartite difficulty in some of the translations in some of the stories in A Chapter of Hats? Could you also tell us what criteria you adopted for the selection of the stories in the collection, and how you viewed previous collections?

JOHN GLEDSON: The words are quoted from the introduction to A Chapter of Hats (p. 10). It's not easy to relate such abstract words to concrete examples from the stories - they don't apply in any simple way to a given sentence, and I don't think I thought in those terms as I was translating - it's more intuitive than that. But there are perhaps certain moments when you are aware of a balance to be maintained. An obvious case is when there is a narrator involved, with whom the author is more - or less - in sympathy. This affects every word of Dom Casmurro, of course, and means several balancing acts: it is important, always, to get Bento's actual tone right, and it's not simple. For instance: he is a lawyer, but he is not anxious to

\footnotetext{
${ }^{8}$ See $<$ http://www.theguardian.com/books/booksblog/2013/mar/01/survey-short-story-machado> .
} 
bring this fact to the fore, except very occasionally, and towards the end of the book, in Chapter 138, where he actually mentions "the first eyewitnesses in our law-courts". The same problem with narrators is present in "Singular ocorrência" [A singular occurrence], as I have illustrated in my essay. When I looked at the version by Schmitt and Ishimatsu, I found that in a few cases there was (I thought) a failure to appreciate that the two speakers in the story are in a sense "complicit", or sympathetic to Andrade: for instance, the phrase "ele tinha em alto grau a paixão das mulheres", which I translated as "he had a great passion for the ladies", they translated as "he was an inveterate skirt-chaser". Maybe Andrade was an inveterate skirtchaser, but that's for us to work out, if he is - the narrator doesn't call him anything so demeaning. In each case, we have to work out the distance expressed in the words. But this is even the case in stories where there is a so-called "third person" narrator, for Machado, at least after 1880, never takes a simple "un-thought-out" narrative stance: he is always aware of the level and tone of his irony. For this reason, it makes no sense to divide his work up in any simple way between first- and third-person narrators. Narrative unreliability and irony are perhaps two forms of the same thing.

As for the selection, as I have said, I deliberately put the emphasis on the stories from the 1880s, which I think are his best, at any rate his most obviously appealing. I was also influenced by the fact that there already exist at least two translations of "O alienista" (and it is very long), and Caldwell and Grossman's collection gives pride of place to the stories of Papéis avulsos, where Schmitt and Ishimatsu chose only stories that had not been in The Psychiatrist and Other Stories. I wanted to make a new start, on principles of my own. Apart from that, the outstanding quality, interest and popularity of some of the stories mean they choose themselves. At the edges, there are some stories I might have liked to include, like the only recently rediscovered “Terpsícore”, but I wanted above all quality. I don't think the topics of the stories (slavery, for instance, or the position of women) really had any final say.

ST: You open your essay Translating Machado de Assis, republished in this number of Scientia Traductionis, with an epigraph from Paul Ricoeur's Sur la traduction: “...la tâche du traducteur ne va pas du mot à la phrase, au texte, à l'ensemble culturel, mais à l'inverse: s'imprégnant par de vastes lectures de l'esprit d'une culture, le traducteur redescend du texte, à la phrase et au mot." What are the risks of understanding the task of the translator in an inverse manner to that of Ricoeur? Could you expand on your interpretation of the epigraph?

JOHN GLEDSON: The epigraph was put in as an afterthought. It instinctively seemed to me to be true, and to express my own attitude to translating. I myself have come to translating through a long acquaintance with Brazilian culture and the Portuguese language (I first came to the country in 1970, and only began to translate books in about 1990); I don't know about the "vastes lectures", but through my acquaintance with Brazilian poetry, fiction and historical writing over the years, and frequent visits, three of them quite long, I have got some kind of familiarity with the country's culture in the widest sense.

But I now wonder if I was being over-dogmatic, or basing my ideas too much on my own experience. I have a reasonable knowledge of Spanish, French and Catalan, but I would never dare to translate complex literary works from those languages. Nor, what might seem more surprising, would I translate books from Portugal, Angola, or Mozambique, etc. - because my acquaintance with those countries, their histories and cultures, and above all their ways of speaking (markedly different from spoken Brazilian Portuguese), is insufficient.

However, I have to recognise that there are translators, and very effective and successful ones, who do translate from more than one language. Some too do things I would never do, yet apparently successfully - David Bellos won a prize for his translations of Ismail Kadare, 
though he knew no Albanian, and used a French translation. Certainly, the ability to translate per se, to get a good English version, is a talent in its own right, and there may be something like a "poetic" sense of the original which gives certain people an access to the meaning and an ability to recreate it in a convincing way that others don't possess. But nothing is going to protect even such people from false friends, and intuitions that are wide of the mark.

ST: Before your translation of Dom Casmurro (1997), the novel had been translated twice, by Helen Caldwell (1953) and Robin Scott-Buccleuch (1992). It's well known that the second translation cuts nine chapters from the novel - an abridged version, perhaps? This said, what motivated and justified your project for a third translation?

JOHN GLEDSON: The Scott-Buccleuch translation is not very good - it's not just the nine chapters he omitted. I have no idea why he did this, and Daphne Patai, who is more persevering than I am, was unable to find a reason. I don't think it was really an intended abridgement, because in that case, why not call it that, and give a list of the chapters by numbers (there is no such list)? Though of course it wasn't just an oversight either - it was done in a calculated fashion. He is very often off-track, in a myriad of small ways; he takes far too many liberties. I was amused to read recently a commentary on another of his translations that it "was like reading the book under water"! Anyone who thinks that "agregado" should be translated as "friend of the family" doesn't know much about Brazilian society or culture, where relations of favour and dependency are fundamental.

Helen Caldwell's translation is another matter. If there were no other, it could perfectly well serve, and did, for many years. Two reasons made me think I could better her, and that it was worthwhile to do so. The first is the simple fact that translations wear - forty-odd years is a long enough time for any version to fray at the edges. Dostoevsky, say, has had numerous translations, and I thought the Oxford University Press were right to want to begin again. The other is a definite failing in Caldwell's translation, which I only saw as I translated myself and compared my versions to hers. Her appreciation of the tone of spoken Portuguese can be a bit "clunky" - not a brilliant adjective, but as close as I can get. I'll give you an example, which I may well have used elsewhere. In chapter 32, Capitu is at her usual task of pushing Bentinho to defy his mother, this time by putting pressure on José Dias to advance their cause - the dependent, however, has done little or nothing. Bento finds excuses for him - he wants to find out first if Dona Glória really has her mind made up ("Se tem a resolução feita"). "Que tem, tem.", says Capitu, with some impatience. Caldwell has "But she is, she is [fixed in her resolve]". But this is not the point; Capitu is not trying to persuade Bentinho of an (obvious) fact, but to force him to the point, and not let him escape with half-measures. I had "Of course she has". It's hard to get an English idiom close to the form of the Portuguese, to give an appreciation of its sharpness and impatience - when I've used this example in lectures, it's easy to convey that, just by "saying" the words "Que tem, tem.", in sharp, whiplash tone of voice. In the original, it doesn't even need an exclamation mark. I know very little about Helen Caldwell, and researchers who have tried to find out more (Daphne Patai and Hélio Guimarães) have failed. I wonder if she spent much time in Brazil. I hope I don't seem carping or unfair, but I think my translation is a real advance on hers.

ST: As has been said, Machado has been celebrated my members of the American intellectual elite. Susan Sontag considered him "the greatest writer ever produced in Latin America”. Others have a more casual, panoramic knowledge of him, like the writer Philip Roth: "Do you know I've only read a single Brazilian writer. I can't remember his name, but it's an ironic novel, with a discontinuous narrative, about a man who recounts his passions and his confusions in the first person. I 
thought it was great." Informed that he was talking about Memórias póstumas de Brás Cubas, he goes on. "That's it! (...) I read it, and I loved it. (...) the critic Harold Bloom, put the work amongst the greatest works of the Western canon and called Machado de Assis a genius." In your essay Translating Machado de Assis, you are critical of the way Bloom characterised Machado, separating him from his context, and saying that "Machado de Assis is a kind of miracle, another demonstration of the autonomy of literary genius, as far as factors like time and place, politics and religion are concerned, and of freedom from any type of contextualisation that supposedly determines human talent." ${ }^{10}$ Wouldn't it be more sensible to recognise Machado's individual genius, while recognising that he is indissociable from his context? Furthermore, since Bloom read Rabassa's translation - of which you are strongly critical - might it not be that Bloom reached his conclusion from a mistaken impression of the novel and its author? Or is Machado's genius immune from mistaken translations?

JOHN GLEDSON: When foreign writers come to Brazil, often to promote their own work, they suddenly are faced, when interviewed by local journalists, with the "duty" to know something about Brazilian culture. The result is embarrassing comments like these - I remember interviewing John Barth years ago for a programme on BBC radio, and finding out that he had last read Machado about 30 years ago - though at least he had read him then with real interest and benefit. A good introduction to the Caldwell translation of Dom Casmurro, by Waldo Frank (who knew Brazil and Latin America well), was jettisoned for one by Elizabeth Hardwick, the one who tells us that Machado's mother was "Spanish, from the Azores". Much as I want Machado to be read and enjoyed, I find these statements, and the ignorance they sometimes spring from, in the end unhelpful.

Harold Bloom is an extreme case of the same attitude, the more so as he is a renowned literary critic. I don't think Rabassa's translation has much to do with it - I would be surprised if Bloom had not already read the earlier Grossman translation, which is much better, and decided to be nice to the new translation with perhaps a cursory acquaintance with it; and while reading it is not a pleasant experience (even for someone who can't read the original), it is a translation of the novel.

I suppose we should recognise the "individual genius" which is at the same time “indissociable from its context”. The trouble is, however, that these words don't explain very much. We want to know - and we can know - much more about the ways the two, the man and the milieu, interacted - including, of course, the "foreign" milieu, the books and newspapers Machado read. The trouble is perhaps with the word "genius", itself, which implies that he is somehow incommensurable. As I said in the introduction to A Chapter of Hats, if Machado had not existed it would have been difficult to invent him - but that is not to say that he does not have the most intimate connections with the society he came from (and knew it, and was proud of it). After the work of Roberto Schwarz in particular, and of others like Raymundo Faoro, we should be able to get beyond these divisions.

\footnotetext{
${ }^{9}$ See <http://revistaepoca.globo.com/ideias/noticia/2011/09/philip-roth-cultura-literaria-vai-acabar-em20-anos.html>.

${ }^{10}$ BLOOM, Harold. Genius: The Hundred Most Creative Writers in the History of Literature (New York: Warner Books, 2000), p. 545.
} 
ST: In the second section of Translating Machado de Assis, you compare two passages of Memórias póstumas de Brás Cubas in translations by William Grossman and Gregory Rabassa, and then compare your own translation of Dom Casmurro with those by Caldwell and Scott-Buccleuch. Although you are rather critical of the other translations, we would ask: as Borges says in Las versiones homéricas, about the multiple versions of the Odyssey, couldn't we say that the several translations of Machado's novels have something of value to offer in the translation and enjoyment of his works? Also, is this diversity of translations necessarily a setback for the reception of Machado in the English-speaking world, or might they turn out to have some kind of use in some future moment?

JOHN GLEDSON: Let's try to distinguish, and get things into perspective: there are such things as bad translations, as everyone knows, and I have come across quite a few in my career. (Can you take seriously someone who translates "ignoro o que pensará dele o leitor" as "I will ignore what the reader will think", or "enxovia" as "anchovy", "cheguei-me" as "he came over to me", or "buzo" (Spanish) as "buzzard"? Just some examples among very many, that come immediately to mind). Usually, you find that people who are inaccurate, careless or ignorant of "details" like these make other kinds of mistakes as well. In my essay on translations of Carlos Drummond de Andrade's poetry into English (in Influências $e$ impasses, pp. 281-299), I looked at two anthologies that I would consider to be bad translations, though they are bad in different ways, and for different reasons. I find it impossible to think of anyone getting much benefit from them (perhaps from the odd poem in Virginia de Araujo's collection, but how would they know where to look?). The proof, in so far as it is one (and as far as I am aware) is that they have sunk into oblivion. In my answer to your question on the translations of Dom Casmurro, I argued that Scott-Buccleuch's version is bad enough to be unserviceable - though this did not stop me using it when I translated the novel myself; not everything is wrong, and sometimes even his mistakes can set off a train of thought in my mind. A translator needs an interlocutor, and in the absence of people, other translations serve their turn. I think my version supersedes Caldwell's, but there I would be less dogmatic.

Borges's essay is on Homer. In a case like that, where a work has lived for many hundreds of years, has been seen through the eyes of many different periods and cultures, and in which bad, inaccurate translations would not even make it into public consciousness, of course different translations have enormous interest. I mentioned Clive James's recent translation of the Divine Comedy, in which he uses quatrains instead of tercets (and which I haven't read, though I'd like to) - most of the reviews I have read are respectful, some more enthusiastic than others, and refer to previous versions, usually modern ones, by Dorothy L. Sayers, John D. Sinclair, or others. James starts off with two advantages - he is an accomplished poet in his own right, and his wife is a Dante scholar. But it makes no sense to compare this kind of contrast with botched versions of novels, which, I'm afraid, Gregory Rabassa and Robin Scott-Buccleuch have produced. It would be nice to think that good translations improve the works' chances of making their way in worlds outside their native language. Surely, though, we can be certain that bad translations, though they may I suppose be better than nothing, can't help? 
ST: In an interview with André Luis Gomes for Revista Anpoll, ${ }^{11}$ when you are discussing the possible reasons for Machado's work being little known outside Brazil, you say the following: "My frustration is that, when I'm translating Machado, I increasingly realise that this is great literature, but that a good part of the greatness is to be found in details (as Roberto Schwarz said, Machado is "detalhista ao extremo" ["extremely attentive to detail"]), in tones of irony etc., which - while they're not untranslatable - don't immediately strike the reader". Could you say a little more about this? Why do you think this "detalhismo", that you and Schwarz see, is not enough to lift Machado, through translations, to fame and international literary recognition?

JOHN GLEDSON: Perhaps it would be as well to make a distinction again, (and perhaps I should have been clearer in that interview). Often, it is perception of the implicit meanings often, hearing the exact tone of the irony - that makes us aware of the ("hidden") depths of Machado's understanding of human nature and society. This is not exactly the same as saying that his greatness is the product of these moments, inheres in them, or is to be identified with them or limited to them. Rather, through them (and, it is to be hoped, through good translations, and even good interpretations), we sometimes reach a greater understanding of the depth of Machado's thinking and perception, remarkably unconstrained by the limitations of his milieu, and even his time. It is difficult to illustrate this without going into seemingly unnecessary detail, precisely because so much depends on context (which is why it is not just the "details" themselves that reveal the greatness - they cannot be isolated from the whole work).

Let me try to give one example, from a crônica (where the total context is at least relatively short...). The crônica for "A Semana" of $9^{\text {th }}$ February 1896 starts with a newspaper advertisement (probably real, perhaps fabricated) by someone who says he's worked in the secret police in London and New York. This man, it seems - or so Machado imagines - is good at clearing up mysteries, and he goes into some famous examples of mystery identities (the Man in the Iron Mask, for example), finally coming to a more recent (and certainly real) case, of the suicide of one Ambrosina Cananeia, who killed herself to stop a younger female friend of hers, "uma mocinha de dezesseis anos" [a sixteen year old girl], being persecuted by her family because of their "amizade" [friendship]). What explains this tragic event (Ambrosina also left behind two children and an old mother)? I'll quote the last two sentences: "Ao médico não custará dizer que é um caso patológico, ao romancista que é um problema psicológico. Quem eu quisera ouvir sobre isto era o ex-secreta de Londres e de New York, onde a polícia pode ser que penetre além do delito e suas provas, e passeie na alma da gente, como tu por tua casa." ("A doctor would say that it's a case for the pathologist, a novelist for a psychologist. The opinion I'd like to hear is that of ex-secret policeman from London and New York, where perhaps the police get beyond crime and its proofs, and walk around people's souls, just as you do in your own home."). Suddenly, in these last few words ("e passeie na alma da gente...") obviously bursting with irony, the whole crônica comes together to a (somewhat savage) point - of course we don't understand one another in that way, but that doesn't stop us thinking we do, and destroying people's lives.

I hope this example illustrates what I mean - the details and the total context can't be separated from one another (as in fact Schwarz says, for he too is talking about the relationship between the details and the larger whole). For that same reason, details alone are not enough to give Machado his deserved fame - but he does demand a translator who is willing enough to give them careful attention; otherwise there are multiple pitfalls; we have

\footnotetext{
${ }^{11}$ See: <http://www.anpoll.org.br/revista/index.php/revista/article/view/38/21>.
} 
always to be on our guard, with our ears open (“de ouvido alerta"). Perhaps, on a pessimistic view, it's hard for a translator to make a good version of Machado, but fatally easy to make a bad one.

ST: In his brief essay "Uma feliz coincidência, ou confluência: John Gledson e Machado de Assis [A happy coincidence, or confluence: John Gledson and Machado de Assis]", published in the book Machado de Assis - tradutor e traduzido, ${ }^{12}$ João Hernesto Weber comments on what he considers are the "elective affinities" between the writer and the critic. "It is the meeting between an English literary tradition, and a Brazilian writer who drank at the fountain of the English literary tradition. Perfect. 'The Hand and the Glove'." As he says, Machado was influenced by English writers, particularly Shakespeare, Sterne, Byron and Swift. With this in mind, how do you see the English influence in Machado? Also, what references and models of literary writing in English did you think of and use in translating Dom Casmurro and A Chapter of Hats?

JOHN GLEDSON: I find this question difficult to answer. There is no doubt in my mind that Machado knew English well, and that his knowledge of it increased considerably during the 1860s and perhaps particularly the 1870s. There are French translations of English works (many of them) in his library, alongside many in the original, but it is clear from many small pieces of evidence that he read English well - a quotation from Clarendon's History of the Rebellion and the Civil Wars in a crônica of 1878, for instance, or two words from Tennyson - "Labouring up" - used as an epigraph to Falenas (1870). Probably, as João Roberto Faria argues, ${ }^{13}$ the trigger was above all Shakespeare, whom Machado adored - he calls a festival to celebrate him "as festas do gênero humano" in one of the crônicas of "A Semana". It seems that Machado first saw Shakespeare's plays on the stage in about 1870, with the great actor Rossi. He quotes Shakespeare a great deal too, and not just the obvious phrases. Eugênio Gomes was the first to study the matter systematically. But these are external facts, not a real understanding of the depth of the influence - how fundamentally was he affected by Sterne, say, and which Sterne: The Life and Opinions of Tristram Shandy, A Sentimental Journey, or both? Or Swift, whom he uses a few times (e.g. in the crônica from "A Semana" about the mules that pull the trams in Rio). It may just be impossible to generalise about a "national" influence - how could we distinguish between the influences of Swift, say, and Voltaire? Sometimes, I think that too much emphasis is put on Machado's affinities with $17^{\text {th }}$ and $18^{\text {th }}$ century writers - quite often, he quotes them in contexts which cast an ironically $19^{\text {th }}$ century light on them. I can recommend Chapter 90 of Quincas Borba, where he uses and amends La Fontaine, as a very illustrative example.

I don’t know about (English, or British) national character, which João Hernesto assumes in his generous comments, and find it difficult to talk about, perhaps because I can't get the required distance from myself. Irony may have something to do with it - Americans, I know, often find the British irritatingly ironic, and I can sympathise with them. It's easy to put one's foot in it by intending to be taken ironically and being taken seriously - at least I find that.

I can't say I ever use any one writer consciously as a model when I'm translating, and am always admiring of translators who do - though usually they do so in contexts more “extreme” than Machado's novels or stories. I recall one case of Paulo Henriques Britto doing

\footnotetext{
${ }^{12}$ WEBER, João Hernesto (2012). "Uma feliz coincidência, ou confluência: John Gledson e Machado de Assis”. In: Guerini, Andréia; Freitas, Luana Ferreira de; Costa, Walter Carlos (Orgs.). Machado de Assis: Tradutor e Traduzido. Tubarão: Ed. Copiart; Florianópolis: PGET/UFSC.

${ }^{13}$ See FARIA, João Roberto. Machada de Assis do teatro. São Paulo: Perspectiva, 2008. pp. 83-90.
} 
so in the translation of an American novel partly set in the $18^{\text {th }}$ Century - "Mason and Dixon" by Thomas Pyncheon, I believe -, and which pastiches English language of that period. But Machado isn't like that, and I'm content to let my general knowledge of English and Portuguese do what it can. What I said above about Machado's use of earlier writers makes me think I'm right. Really, I suppose I'm saying that using someone else's style as a model in this way would risk putting Machado in a straitjacket: in the end, writers are too individual to be transferable in this way.

ST: In Translation Studies, the relationship between translation and power has received a greater deal of attention in contemporary debates. In the Englishspeaking world, Lawrence Venuti's arguments (1995 and 1998) about how foreign literature is translated into English have been a great instance of that. Venuti identified a "domestication" of foreign works, an ideological attitude which results in a fluent English, easy to read, and linked to a lack of concern with the cultural specificities of the texts, more so if they do not belong to a "canon". In your Translator's Introduction to A Chapter of Hats, you inform us that all of Machado's ten novels have been translated into English. ${ }^{14}$ If Machado does not (yet?) belong to a worldwide canon, how do you see this as regards their "domestication"? Can you see the marks of this kind of fluency, and lack of respect for cultural specificities in translations of Machado's work? Do translators fail to respect the idiosyncrasies of his style?

JOHN GLEDSON: I think we have to be careful here - there are different ways of seeing this "domestication", and I feel more in sympathy with Antoine Berman, and his notion of "l'auberge du lointain", according to which foreign works are generously given shelter in a new context, than with Venuti, who puts greater emphasis on the visibility of the translator. However, my position may well be limited by the kind of works I have translated. This is not to say that I don't feel aggrieved when I am ignored, and my work taken for granted, by other people in the process, as has happened once or twice - then, if you can, you must assert yourself. But I don't think I am in a position to assert myself in the face of the original: as I said earlier, we should be self-effacing mediators, not protagonists. The two poles I operate with are the author's intentions (this has always been a principle in my literary critical work, and I have always been overt about that), and the production of an accurate, readable English version which doesn't "read like a translation" - if it does, and more so if it's deliberate, it simply brings the reader into frustrating, because impossible, "contact" with a language he or she doesn't know. Of course, the major limitation I have in voicing this opinion is that the works I have translated are none of them so distant from our own world as to require a huge imaginative effort, nor is their language too idiosyncratic. I have (almost) never translated poetry for example. I have lived with the poetry of Carlos Drummond de Andrade for more than forty years, and phrases of his keep popping into my head at unexpected moments. I also know that he thought of English as "the most enchanting language for me" ("A língua mais encantatória para mim"), as he said, and feel a certain shame to have tried so little - there is a good anthology, edited by Mark Strand and including Elizabeth Bishop's translations, but he deserves much more. I guess that the wonderful natural rhythms that help make his poetry so memorable are so easy to destroy, and so difficult to replicate, in another language.

\footnotetext{
${ }^{14}$ Editors' note: a list of every translation of Machado’s novels into English is published in a separate document in this issue of Scientia Traductionis.
} 
Machado is not exactly "non-canonical”. He’s recognised as a classic, and as a great writer the only thing we have to do, or can do, is make sure that good versions of his work exist. I can't really comment on other translations of his work, apart from those I have already mentioned (Grossman, Rabassa, Caldwell, Scott-Buccleuch and Schmitt and Ishimatsu) because I haven't sufficient familiarity with them. It may be that the failings of some of these projects have to do, to a greater or lesser degree, with an assumed cultural superiority - but I wouldn't like to affirm this too confidently, for it may be explained by other simpler things.

\section{ST: In your opinion, which works or collections of works by Machado should by translated for the first time, or retranslated into English? Why?}

JOHN GLEDSON: Now all the novels have been translated: I am reluctant to say if any need retranslating, largely from ignorance (I don't read translations of works in languages I can understand in the original, except for purely professional reasons), though also from tact and reluctance to criticise others. My criticism of Gregory Rabassa's translation of Memórias póstumas de Brás Cubas was the product of my shock and disappointment of what translator and publisher had done, and the importance and reputation of both, which was going to give a spurious lustre to a bad translation. Something had to be said, and I'm only sorry (and grateful to Scientia Traductionis), that it's taken so long to reach a wider public.

If I had the time, and simply as a labour of love, I would like to retranslate Quincas Borba my impression (which is all it is) is that Clotilde Wilson's (1954) translation is good, as good as Helen Caldwell's Dom Casmurro, and that Gregory Rabassa's (1998) has the same gaucherie and lack of feel for Machado's irony and his rhythms as his translation of Memórias póstumas. But I have a particular affection for this novel (underestimated in general by critics), which I have spent time studying in its two versions (in feuilleton form and as the completed book), and for which I recently wrote an introduction to a new Brazilian edition (by Penguin-Companhia das Letras), which tries to get it into a perspective closer to Machado's real intentions, and to focus on the novel's "meat", which lies in the central plot, involving Rubião, Sofia and Palha. Translating it, trying to get its tone and sharpness just right, would be a fascinating experience.

ST: Finally, a suggestion for the future: how about producing a second collection of Machado's stories? Amongst the more than 200 stories he wrote, and amongst those not yet published in any of the five existing collections, which stories would you choose and why?

JOHN GLEDSON: This too is a difficult question to answer. Whatever I choose is bound to look like the "second team", and thus be less attractive to a publisher; and I only have the two collections I have mentioned, The Psychiatrist and Other Stories, and The Devil's Church and Other Stories, available to me. And, of course, many of the stories are not in the first team anyway, including almost all those written before 1880, which are often interesting, but can seem naïve and limited to any audience, Brazilian or foreign. Within those limitations, however, I can offer one or two choices, and reasons why I would choose them. For obvious reasons, anthologisers, including me, have chosen stories Machado himself included in his own collections, and it is always possible to question those choices.

One, which I was surprised to discover had not been translated (unless it's in one of the anthologies I haven't seen), is "Dona Benedita”, a long story from Papéis avulsos, rather complicated and heavily ironic, but fascinating. One or two others from the same collection have not been "done" either, notably "O empréstimo", "O anel de Polícrates", and "Uma visita de Alcebíades". Probably they seemed too slight, but they all have more substance than appears at first sight. 
Of the later stories, one that I have had a soft spot for since it was first "rediscovered", and very nearly put in the anthology, is "Terpsícore", which I mentioned earlier. It's short, set amongst the lower, impoverished classes, and very "Brazilian" in the sense that it revolves around dancing. The whole story is justified by a wonderful description, accurate and poetic, of Glória dancing what is obviously a kind of samba as a "mistura de cisne e cabrita" - a neck like a swan and feet like a goat! It also has one of those endings profoundly typical of the genre which leave everything in the air, in an impasse with nothing resolved, of which the most famous is perhaps Chekhov's "The Lady with the Lapdog”.

No doubt there are others. I'm beginning to think that second anthology would be worth doing after all! It would be interesting to include a few of the best crônicas, though I would have to be careful they didn't need much annotating - "O punhal de Martinha", "O autor de si mesmo", and "Conversa de burros", for example.

Gustavo Althoff gualthoff@gmail.com Scientia Traductionis 